\title{
The Representation of Women in N.H.Dini's Pada Sebuah Kapal: The Reflection of Women Cultural Identity of the 1970s.
}

\author{
Dwi Wulandari ${ }^{1 *}$ \\ ${ }^{1}$ English Department, Diponegoro University
}

\begin{abstract}
This study is aimed at finding how women is presented in N.H. Dini's Pada Sebuah Kapal. This novel is written with the setting time in 1973, and therefore the story evolves by depicting the culture of the 1970s. By acknowledging the facts of the new order in Indonesia, it is particularly interesting to see how women in those years are depicted in the relevance of today's women condition. This study reveals the facts that though women may seem to have a choice of her own regarding her life, they are subjected to the many limitations set by the society. There are standards that need to be met in terms of appearance, behaviour, and even thought if such women are hoped to be accepted within the society. Another point worth noted is the fact that being accepted by the society then is used as the parameter to define whether the women can be described as being happy or not.
\end{abstract}

\section{Introduction}

In general, every society has developed a clear picture of how men and women should look alike, both in appearance or behaviour. Such a picture has been developed as part of their social interactions. Because men and women are believed to have different roles, the representation of their appearance and behaviours need to be considered as different as well. In some cultures, women are considered the ones who should have better behaviour, talk in a better manner, and show a lower degree of assertiveness than men [1]. One of the arguments [1] mentioned that women share the role as mothers to whom the society leads the hope to care for the better generation and therefore are expected to talk and behave better.

How women are portrayed can also be seen in literary work, including in novels. Even though novels are mostly fictional works, it is used as a medium for the writers to depict the events and their ideological concepts of society's social relation conditions. Therefore, how women are depicted in the novel may become the actual depiction of women within their natural social relations. Some research has been done to reveal how women are represented in the novels. [2, 3, 4, 5] especially look into how girls are portrayed in the novels. Their studies show how girls are related to particular facts of social relationships, such as the ones related to romanticism and sexuality, their consumptive culture, or their identity construction.

* Corresponding author: wulandaridwi76@gmail.com 
As the very fact that those studies are focused on girls' life, the representation is mostly depicted as an available type of woman. However, it still addresses similar issues applied to all stages of women, such as romanticism or consumptive culture. Other research focusing on the representation of adult women are conducted by $[6,7,8]$. Their research also focuses on how women are perceived in terms of their roles in society, being polite, and the standard of beauty attached to them. In line with what is mentioned by [1], most of the studies emphasize the women as feminine figures who should hold morality highly, especially with the language they are using $[7,9]$ because women are considered as part of the fragile ones in the society [10]. Therefore they need to show those 'good' behaviours to get protection from the more powerful part of the society, that is, men. However, some other studies also show some basic changes regarding how women are depicted. Novels studied by $[5,11]$ show that the picture of 'good' women in the fairy tales has shifted to the picture of more powerful women, have a strong will, and are sexually more progressive as they can distinguish which one is real and which one is in fantasy.

This study is to take a look at how the life of women is portrayed in the novel. The pictures rely on the representation of a woman from single life into married life and motherhood. It is interesting to see how the representation of women evolves from one stage of women into another, especially the one depicted nearly five decades ago. Pada sebuah Kapal, a novel written by N.H. Dini [12] is used as the location of the study, as the data will evolve on the representation of women in that novel. This novel is exciting to be used as the source data because, in this novel, the depiction of the women is carried out from being unmarried women into a married one and motherhood. N.H. Dini's Pada Sebuah Kapal is used as the location and source of the data because of N.H. As the author of the novel, Dini was a well-known author who is prominent in working with the story focusing on the life of women. Her novel mostly revealed her critics of the social construction imposed on women at a particular time. It is interesting to see how her ways of social critics for women identity, revealed in Pada Sebuah Kapal that was written in the 1970s, are still relevant to the social construction imposed on the women of present days.

\section{Methods}

This this study uses discourse analysis perspective in analyzing the texts because the data analysis is relied on how text is discursively produced as part of social reality. Discourse analysis is used as the perspective in this study because this study explores the discursive product of social reality [13].

This study is a descriptive qualitative study because this study describes the linguistic phenomenon qualitatively. The data used for the analysis are in phrases, clauses, and sentences that show how the women are represented in the novel and the context that builds the utterances.

The source of the data is taken from Pada Sebuah Kapal, a novel written by N.H.Dini in 1973 published by PT Dian Pustaka Jaya. This novel is very popular and has gained much admiration from its nationwide readers, so that the novel is reprinted many times by a bigger publisher, Gramedia Pustaka Utama. The one used for the analysis in this study is the 9th edition, printed in 2009 and has 350 pages.

The sampling taken for the study is the purposive sampling based on the fact that the data analyzed represent the whole population but more of the data that shows how women are portrayed in the novel.

\section{The Representation of Women in Pada Sebuah Kapal}


The the study focuses on how women are portrayed in Pada sebuah Kapal, written by NH Dini. The novel tells a story of the life of Sri, a Javanese woman from her young age as a child until her marriage life. Sri grew up in a family that valued art as her father was a painter, and one of her brothers was very close to her. Sri herself developed a great ability in dancing, first the Javanese dance and later on the Balinese dance. She was working as a radio announcer, and at the same time, she danced for a big occasion or national celebration. She was married to Charles Vincent, a French diplomat, after her fiancee, the love of her life, passed away in a plane accident. She was unhappy in her marriage life, as her husband could not show love and tenderness as she expected from him. Her unexpected acquaintance with Michel, one of the commanders in the ship that she was aboard during her journey from Saigon to Marseilles, created a love feeling that was so strong that she dared to betray her husband.

\subsection{General Pictures of women in the 1970s}

Women are depicted in various ways, which mostly were related to their appearance as being feminine. Women are set in a particular parameter that should meet certain standards. In Pada sebuah Kapal, how women are portrayed can be seen in several generalized stages.

\subsubsection{Description of single women}

Being beautiful is attached to how women should look alike. The modal verb should be attached here because some standards make women fall into the categories of being beautiful or not. Although the perception of beauty can be relative and subjective, there is a general concept of what is considered beautiful constructed by society. In this 1970 s era, being beautiful is linked with the fact that beautiful women have fair skin and are tall, as shown in data 11 below, and therefore some girls will feel somehow insecure just because they are not tall and have dark skin.

Datum 11

Bakal istriku kulitnya harus tidak begitu hitam, badannya lampai, ... [12, p. 43] ....kau mempunyai rasa rendah diri karena kau tidak tinggi dan karena kau berkulit sawo matang. [12, p. 59]

Another more important notion about women is put on their behaviour. Even at the beginning of her adulthood, women in the 70 s are told that it is a must for a girl to represent fineness, purity, and beauty. They should behave in a really good manner; for example, they must not laugh out loud, show their open mouth; they should show a certain degree of shyness, and therefore are not encouraged to have eye contact while talking to others. Those can be examined from excerpts in data 5,7 , and 15 below.

Datum 5.

Baginya seorang anak perempuan adalah wakil dari kehalusan, kesucian dan keindahan. Kalau kakakku perempuan tertawa terbahak..., ibuku akan mengerutkan keningnya... "seorang puteri tidak akan membuka mulutnya selebar itu... [12, p. 14]

Datum 7

Padanya tidak kudapati sikap malu yang berlebih-lebihan seperti yang kumiliki. [12, p.21]

Datum 15

... aku selalu menghindari untuk berpandangan benar-benar dari mata ke mata. [12.p. 69] 


\subsubsection{Description of married women}

Women are married mostly because they are loved, and there should be many reasons why they are loved. In Pada sebuah Kapal, the most common reason for a woman to be loved is sweet, soft, young, and beautiful, as shown in the following data.

Datum 21

Aku mencintaimu karena kau manis, kau bakal istriku dan kau penari [12, p. 105]

Datum 1.

Lembut, berpikir lamban, dan menikah pada umur sembilan belas tahun dengan pegawai negeri yang berbudi manis....Semakin hari dia semakin cantik [12, p. 12].

Datum 13

Kau lembut. Suatu hari nanti akan ada laki-laki yang mengatakannya dan yang memerlukan kelembutan itu. Dia akan mencintaimu. [12, p. 57]

Datum 16

Kalau kita punya anak, aku ingin dia menjadi seorang yang beradab, halus seperti ibunya... $[12$, p. 79]

Once women enter the marriage life, more standards are put on their shoulders, and most of the standards are set on behalf of the husband. Before marriage life, the girls should know that the husband they should worship, as shown below.

\section{Datum 31.}

Selama dua puluh empat tahun aku dijejali dengan pemikiran bahwa seorang istri adalah bayangan suaminya. Bahwa surga seorang istri terletak ditelapak kaki suaminya. Bahwa suami adalah ratu dan wakil Tuhan yang harus dianut dan diikuti segala perintahnya. [12, p.130]

That heavy burden of how women should treat their husbands makes women feel unconfident to behave as they are, become doubtful that they do have the capacity to keep their husbands' love (datum 25) and even consider themselves not being pretty nor sexy enough to make their husband willing to spoil them (datum 34).

\section{Datum 25}

Sekali lagi aku kembali kepada aku yang semula, ragu ... Apakah aku memiliki syarat-syarat kewanitaan yang bisa menahan suamiku yang kaya agar tetap menjadi milikku? Aku tidak mempercayai kemampuanku. [12, p.114]

\section{Datum 34.}

Aku tahu bahwa aku tidak cantik. Aku tidak memiliki potongan tubuh yang menarik selera...aku merasa iri kepada isteri-isteri yang kelihatan amat dimanjakan oleh suami mereka. [12, p. 131]

In response to those insecure feelings, women tend to do something to please their husbands. They are motivated to learn and do dancing (datum 9) or cook the husband's favourite food (datum 26) to secure their husbands love.

Datum 9 
Bukan untuk mencari uang, tapi kau menari untuk dirimu sendiri, buat suamimu dan anakmu kelak. [12, p. 36]

Datum 26

Karena aku percaya akan kata orang bahwa cinta seorang suami amat tergantung pada kesanggupan istrinya memasak. [12, p. 120]

Apart from the willingness to do things to please their husbands, women are also aware that they should be the source of comfort for their husbands, and therefore they may not show miserable faces because their faces are where their husbands seek consolation, as seen in the datum below.

Datum 23

...kata-kata ayah yang mengharuskanku untuk tidak mengerutkan kening karena wajah seorang anak perempuan adalah wajah tempat berlabuh, teduh dan temaram. (12, p.106]

The understanding that women should always obey their husbands (datum 31) triggers them to show agreement in whatever cases even though they disapprove deep down in their hearts. In Pada sebuah Kapal, such agreement is still expected even though she undergoes dreadful treatment, and all she feels is a burst of anger. However, she chose not to reply to her husband's bad words (datum 32) and chose to accept such bad treatment while crying quietly to console herself (datum 30). She feels the need to obey her husband's desire for sexual intercourse simply because she is his wife, thinking that she is part of his belongings (datum 27).

Data 32.

Setiap kata suamiku kusetujui meskipun dalam hati aku menyangkalnya. Setiap tindakan keras hanya kupandangi dengan mata sedihku. Dan setiap kata-katanya yang kasar kutanam dan kupendam dalam-dalam tanpa kujawab [12, p.130].

Data 30

....aku telah berdiam diri ditekan oleh keharusan untuk menelan dan menerima segala perlakuannya .... aku hanya mempunyai satu cara menenangkan diri, ialah menangis diamdiam disudut yang tidak dilihat orang. [12,. p. 130]

Data 27

Aku mau tidur dengan dia karena aku membiarkan diriku berfikir bahwa aku menjalankan kewajibanku. Aku diberinya makan dan atap. Aku merasa seperti sebagian dari barangbarang rumahtangganya. [12, p. 129]

\subsection{Description of women related work}

Aside from the general pictures of women as wives, this novel also acknowledges that women may also have another world: the world of work. Though not much is said about what women are capable of doing in earning money because this novel is centred on the life of Sri, who was a radio announcer and a dancer before she got married. However, some of the womenrelated work mentioned in the novels is familiar with what women have done, such as cooking (datum 4) and crafting (datum 2). Even if women are working, most of them are aimed only for extra income (datum 4).

Datum 2 
Dibikinnya keranjang-keranjang dari rotan dan rumput kering, anyaman-anyaman bambu untuk tempat bunga... [12, p. 13]

Datum 4

... terlalu sibuk dengan pekerjaan sampingan: membatik, membuat kue, untuk sekedar menambah penghasilan. [12, p. 14]

Even if women have steady work to support themselves financially, most of such work is naturally women's work. In datum 3, even if she is learning and attending good high level of the school, in the end, she works as a seamstress and uses her connections in the university for her costumers.

\section{Datum 3}

.... ketika dia pindah ke Yogya untuk memasuki sekolah tinggi yang baru dibuka, dia menjadi tukang jahit yang rapi dan dikenal oleh golongan pelajar di kota tersebut. [12, p. 13]

Another notion worth noting in the description of women work is that their job may be underestimated. In datum 8 , women who work as stewardesses are ridiculed, and the job is considered dangerous because the flight crew are mostly males. In datum 12, men explicitly think that women will not be able to work without making such a fuss and petty quarrel among them.

Datum 8

Apalagi awak pesawat terdiri dari laki-laki semuanya. Mereka membayangkan hal yang buruk-buruk saja. [12, p. 24]

Datum 12.

Dia hanya akan berfikir: perempuan tidak dapat bekerja tanpa pertengkaran-pertengkaran remeh yang menyialkan nasib. [12, p.49]

\subsection{Description of motherhood}

It is only natural actually that motherhood comes after the marriage. In many cultures, women are considered the bone of parenting, suggesting that it is the mother's task to raise the child, to provide care and loves. Not only had that, Smyte (2006), in her study, found that the future academic success of a child relies heavily on his or her mother. Though this creates gender inequalities, society put caring for the child as the definition of a good mother. Therefore, this is also what is described as being a mother in this novel; that she wants to be a good mother, even if she has to suffer a bit (datum 37), and that she will never leave her child (datum 50).

\section{Data 37}

Aku sudah mempunyai anak dan aku ingin menjadi ibu yang baik, meskipun aku harus menderita sedikit. [12, p. 145]

Datum 50

Aku telah berkeluarga, aku tidak akan bisa meninggalkan anakku begitu saja. [12, p. 216]

However, in a situation where unhappiness fills the life of the women, children may become the burden. Thus, although women will naturally want to be good mothers, they may 
say or do otherwise. In this novel, due to her hurt feeling and her anger toward her husband, Sri blatantly tells her husband that she is not willing to take the trouble to raise her child, and will put her in the orphanage as she considers raising her child will give her more burden (datum 39). Her love for her child is drowned by her thirst for love, her desire to love and to be loved (datum 45 ).

\section{Datum 39}

...aku juga tidak akan mau bersusah payah ....Dia akan kuberikan pada sebuah rumah penitipan anak-anak. ...bagiku anakku akan merupakan penghambat yang besar kalau aku harus bekerja ... [12, p. 148]

\section{Datum 45}

Kecintaanku kepada anakku adalah kecintaan ibu muda yang haus akan kehidupan yang selama ini diidamkannya, kehidupan cinta dan nafsu bersama laki-laki yang mencinta dan dicinta. [12, p.192]

\subsection{Description of women's view on love and men}

Women also have their thought about love and men. For women, loves is highly appreciated and considered as one thing worth sacrificing. In this novel, when Sri falls in love, she is portrayed as someone who feels free to do as she wishes, feels no doubt or shyness, feels the fineness of feeling as finding her family back (datum 42). How society will judge her love life also becomes one of her biggest concerns. She will feel a great loss of being afraid and ashamed if people think that the man she chose to marry no longer loves her (datum 33).

Datum 42

Aku mencintainya. Aku menulis menurut kemauan hatiku. Dengan dia aku tidak merasa terkekang oleh rasa ragu dan malu yang biasa menguasaiku. Dengan dia aku merasa seolah aku berbicara dengan belahan diriku, seolah aku berhadapan dengan jiwaku yang temaram. Kalau aku memandangnya, aku mendapatkan ketenangan perasaan seperti kalau aku memandang bayanganku dikaca: aku menemukan kekeluargaan yang kukenal... [12, p. $186]$.

Datum 33.

....aku takut dan malu kalau orang berfikir bahwa laki-laki yang telah kupilih menjadi teman hidupku tidak mencintaiku.. [12, p. 131]

For women in this novel, loves is the only trigger for committing sexual intercourse even without marriage. It is the feeling that raises their desire (datum 17), and it is the feeling that will cease away the guilty feeling of committing adultery (datum 19), (datum 40).

Datum 17

Hanya dengan mengingat namanya, hanya dengan melihat dia disana, aku merasa tubuhku memanas [12, p. 83].

Datum 19

Aku tidak menunggu saat perkawinan kami lagi seperti kebanyakan gadis-gadis dari keluarga baik-baik. Saputro telah kembali. Dan aku mencintainya. Apakah lagi yang mesti kami tunggu .... [12, p. 96]

Datum 40 
Milikku yang terakhir itu hanya aku berikan kepada orang yang aku cintai atau kepada laki-laki yang mengawiniku... [12, p.146]

As precious as love is, women also lookup highly at the men they love. In this novel, Sri develops a sense of feeling of what kind of a man she likes and how that man could be the centre of her happiness. Sri likes a strong man, as she thinks that such a man will protect her from every evil in this world (datum 14). This fairy tale thought shows how women feel insecure and that they need men to keep them save.

\section{Datum 14}

Aku senang kepada laki-laki yang kuat. Disampingnya aku merasa terlindung dari segala kejahatan yang ada di dunia ini. [12, p. 67]

With such a fairy tale thought women consider men as the source of their happiness. Women tend to think that their husbands must pamper their wives (datum 47). They also take the man's thought suggesting that it is the man who gave her the baby (datum 20).

Datum 47

Laki-laki seperti dia tidak berfikir bahwa sesudah perkawinan masih ada keharusan untuk memanjakan istrinya ... [12, p. 215]

\section{Datum 20}

Kalau kita kawin aku ingin segera memberimu seorang bayi yang mungil. [12, p. 96].

\section{Datum 22}

Ya, aku telah kehilangan dia dan aku telah kehilangan segala-galanya: seorang kawan dan seorang suami $[12$, p. 106)

So precious men are in the life of women that when they passed away women would feel that they have lost everything (datum 22).

\section{Conclusion}

Although Pada Sebuah Kapal is considered a brave novel at her time due to the frank, outspoken ideas of adultery in the name of love, the basic line for the women pictured in this novel heavily relates the women in their appearance, which values the fineness and feminine look and their roles in the society which centralized as wife and mother. Before marriage, women have learned to value their husband so much, and thus throughout their married life, they tend to do or not to do something to please their husband. Women are considered the second type of everything, compared to men, including the financial support they earned. Another interesting point in this novel is that women are willing to take up love higher as the parameter of their happiness.

This study shows important notions on the progress of how women are imposed with social construction. Even after five decades from the setting of the novels, today's condition of women is not pretty much different. Women of the present day are enjoying the more valuable educational experience, yet the thought of women's lives centred on marriage and motherhood remains true.

\section{References}


1. J. Holmes. Introduction to Sociolinguistics (Reotledge, New York, 2013)

2. N.R. Johnson. Consuming Desires: Consumption, Romance, and Sexuality in BestSelling Teen Romance Novels. Women's Studies in Communication. 33, 1 (2010)

3. A.R. Machado. Female Ways of Representation in the Teen Chick Lits: a Study around the Princess Diaries. Comun.midia consume, 14, 39 (2017)

4. N. Dewi. Formation of Youth Identity in Indonesian Islamic Chick Lit. Jurnal Kata. 13, $1(2011)$

5. R. Fuchs. "Es war einmal ein Dorf, das hatte einen Brunnen und ein grunes Minarett": Fairy Tales and the Image of Muslim Women in Emine Sevgi Ozdamar's Story Collection "Mutterzunge". Colloquia Germanica. 47, 4 (2014)

6. G. Diabah, N.A.A.Amfo. Caring Supporter or Daring Usurper? Representation of Women in Akan Proverbs. Discourse \& Society, 26, 1 (2015)

7. W. Zhang, C. Kramarae. Are Chinese Women Turning Sharp-tongued? Discourse \& Society. 23, 6 (2012)

8. S. Nurhidayah, A.F. Prihantini.Handcuffs of the Beauty Myth in Maupassant's The Necklace. In Proceedings of the BASA International Seminar 20-21 September 2019 Surakarta, Indonesia (2019)

9. J. Wu. "Loveliest Daughter of Our Ancient Cathay!": Representation of Ethnic and Gender Identity in the Miss Chinatown USA Beauty Pageant. JOurnal of Social History. 31, 1 (1997)

10. M.G. Durham. Articulating Adolescent Girls' Resistance to Patriarchal Discourse in Popular Media. Women's Studies in Communication. 22, 2 (1999)

11. M. Sheedy. B.E Wilcox. "Es Was (noch) Einmal”: Grimm Versions of New Fairy Tales in GDR. Colloquia Germanica. 50, 1. (2017)

12. N.H. Dini. Pada Sebuah Kapal. (Gramedia Pustaka Utama, 2009)

13. R. Santosa. Metode Penelitian Kualitatif Kebahasaan (UNS Press, 2017)

14. S. Smythe. The Good Mother: A Critical Discourse Analysis of Literacy Advice to Mothers in the $20^{\text {th }}$ Century. (Unpublished Dissertation of University of British Columbia, 2006) 